\title{
THE ĐA BÚT PERIOD IN NORTHERN VIETNAM: CURRENT KNOWLEDGE AND FUTURE DIRECTIONS
}

\author{
Trinh Hoang Hiep ${ }^{1}$, Damien Huffer ${ }^{2}$ \\ ${ }^{1}$ Vietnamese Institute of Archaeology, 61 Phan Chu Trinh, Hanoi, Vietnam. \\ ${ }^{2}$ Smithsonian Institution, Museum Conservation Institute, MSC, MRC 534, 4210 Silver Hill Rd., Suitland, MD, 20736 , USA. \\ Keywords: Vietnam, Da But, Con Co Ngua, Neolithic
}

\begin{abstract}
This paper presents an overview of the pre-agricultural, ceramic producing, Neolithic Đa Bút culture in its archaeological, bioarchaeological and environmental contexts. Drawing on numerous examples from the 'grey literature,' often published solely in Vietnamese, we review the diversity of known sites and the faunal, floral, material cultural, mortuary and osteological evidence they provide regarding the structure, life histories and foodways of Đa Bút communities. We conclude with a discussion of possible future research directions that would improve what is known about the inhabitants of lowland northern Vietnam during this period, should appropriate new sites be discovered.
\end{abstract}

\section{INTRODUCTION}

The Đa Bút archaeological culture is named after the Đa Bút hamlet, located in Vĩnh Tân Commune, Vĩnh Lộc district, Thanh Hóa province. The type site of Đa Bút was first excavated in 1926 by Patte, being officially described in a 1928 publication (Patte 1928: 186-198), but not being formally announced until 1932. Today, the Đa Bút culture is seen as an important transitional period in Vietnamese prehistory, occurring directly after the Late Hòa Bình-Bắc Sơn period c. 7,000 to 6,000 BP (Vượng and Vinh 2003: 3-8). The distribution of Đa Bút sites to date occurs solely within Thanh Hóa, Ninh Binh and Hà Nam provinces in Northern Việt Nam. Given the numerous technological and social changes that occurred during this period, chief among them the advent of ceramic technology, the inception of open-air coastal settlement sites, changes in mortuary practices, and even tentative evidence for initial cultivation, an overview of what is known about this time period is overdue. This paper presents a summary of the archaeological and anthropological evidence that currently defines the Đa Bút culture, drawing on numerous site reports from the 'grey literature' not readily available outside of Vietnam.

\section{SITE DISTRIBUTION}

More than sixteen sites with stratigraphic horizons bearing Đa Bút material culture are known. They are: Đa Bút, Làng Còng, Bản Thủy, Cồn Cổ Ngựa, and Gò Trũng (Thanh Hóa province), Đồng Vườn, Sáo Cave, Cò Cave, Mo Cave, Đáy Cave, Ốc Cave, Vàng Rock Shelter, and the upper layer of Mòi Cave (Ninh Bình province); and Công 1 Cave, Cồng 2 Cave and Cồng 3 Cave (Hà Nam province). These can be subdivided into two types of site: open-air and cave (Figure 1).

Open-air sites include Đa Bút, Bản Thủy, Cồn Cổ Ngựa, Làng Còng, Gò Trũng and Đồng Vườn, of which Làng Còng and Đồng Vườn are located on hillsides, Gò Trũng is located on a coastal sand spit, and Đa Bút, Bản Thủy and Cồn Cồ Ngựa consist of raised mounds in the centre of modern flooded rice fields (Tấn 1987).

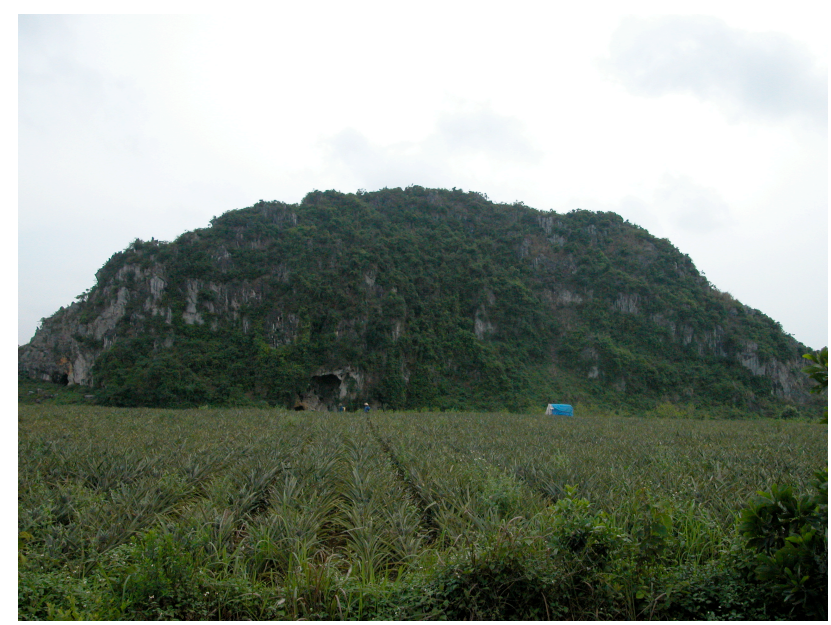

Figure 1. Photograph of Sao cave in Ninh Binh province, excavated in 2001 and 2007.

Cave sites include Sáo Cave, Ốc Cave, Cò Cave, Mo Cave, Vàng Rock Shelter, the upper layer of Mòi Cave (Ninh Bình Province), and Cồng 1 Cave, Cồng 2 Cave, Công 3 Cave and Đáy Cave (Hà Nam Province). They are small-scale and the material-culture bearing strata are often dense with fresh water and salt water mollusc shells (see e.g. Đối and Sử 2002: 12; Sử and Ngọc 2004: 30; 
Hiệp et. al 2008; Hiệp 2008: 90-92; Sử 2012: 20-32; Đối et al 2012: 33-47). With further research, additional settlement sites dating to the Đa Bút Period might be uncovered, especially along the Gulf of Bắc Bộ coast.

In regards to an overall chronology for the Đa Bút Period, only a few dates are currently at hand, and new controversy has surfaced in regards to the antiquity of ceramic manufacture in northern Vietnam, discussed below. At the Đa Bút site itself, charcoal and shell radiocarbon dates range from $6,540 \pm 60$ to 5,710 $\pm 60 \mathrm{BP}$ (Nguyen 2005). The sites of Bản Thủy and Cồn Cổ Ngựa were also radio-

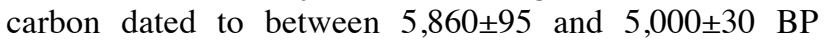
(Vinh 1995; Chi and Hung 2012). At Làng Còng, there are two reliable radiocarbon dates obtained from $A n$ -

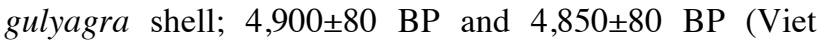
2007), but the two obtained from charcoal are outliers at more than 6,000 BP. Similarly, one radiocarbon date (from charcoal) was obtained from Gò Trũng; c. 4,790 50 BP (Table 1). A generally accepted chronology for the Đa Bút Period can be seen in Figure 2.

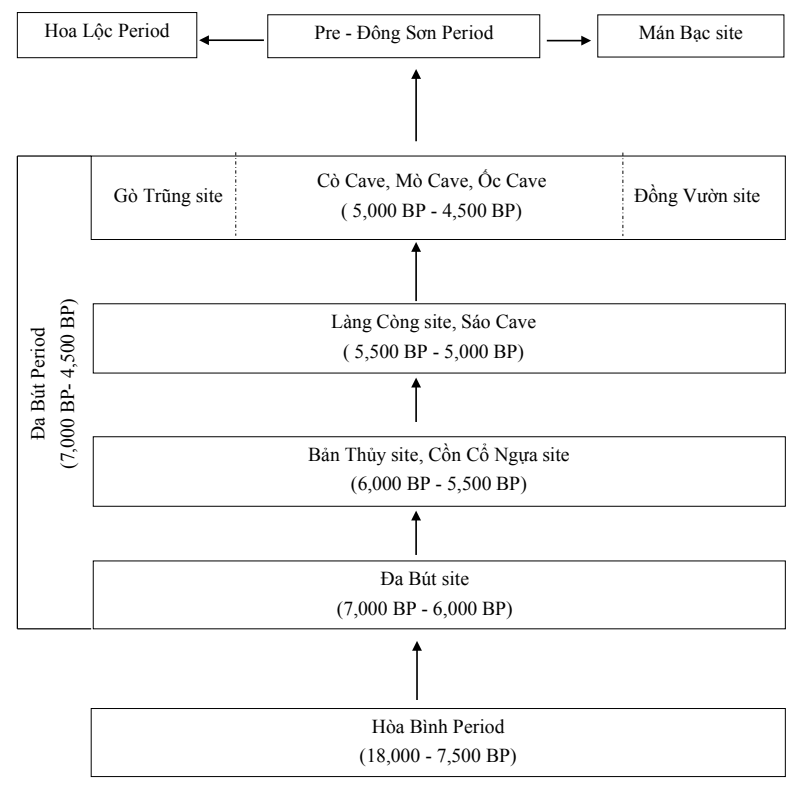

Figure 2. The cultural evolution of the Đa Bút Period in Việt Nam.

\section{ARCHAEOBOTANICAL AND ARCHAEOZOOLOGICAL EVIDENCE}

Faunal remains have been recovered from the majority of Đa Bút sites. Most consist of bone fragments either burnt or broken for collecting marrow, so it is at times difficult to identify them to the level of species or genus. Nevertheless, common specimens recovered include Bovidae, Bubabusbubalis, Bibos sp., Bibos sp., Canidae, Canis sp., Suidae, Sus scrofa, Elephantidae, Elephasindicus, Felidae, Felistigis, Felis sp., Cervidae, Cervus sp., Rusa unicolor, Muntiacus muntjac, Mustelidae, Arctonyx collaris, Hystricidae, Hystrix subcristata, Trionychidae, Pelochelys bribroni, Cyclophorus sp., Angulyagra polyzoneta, Antimelania costula, Tarebia granifera, Placuna placenta, Meretrix meretrix and Acra sp.

A morphological comparison of ulnas from domesticated dogs and those recovered from Đa Bút itself, Patte (1928: 68) suggested that the Đa Bút population was already familiar with and living with domestic dogs. Much more recent genetic (e.g. Pang et al. 2009; Ding et al. 2012) and archaeological evidence (Oxenham and Matsumura 2011; Piper et al. 2014) gives credence to the suggestion that the domestic dog was present in Vietnam by at least $4,000 \mathrm{BP}$, if not earlier. In regards to other domesticates present at Đa Bút sites, Long (1979: 54) originally assessed the faunal bones found from the excavation of the Đa Bút site itself in 1971, and the results demonstrate that $42 / 60$ samples were identified as buffaloes, wild and domestic cows, deer, muntjac and badgers.

Numerous remains of freshwater and marine species were also recovered, including many fish vertebrae, sea crab pincers and fresh-water mollusk shells. Most of the faunal remains found in the Đa Bút site assemblage itself, according to Long (1979:54) belong to herbivorous ruminates and ungulates (83\%). Accordingly, Long (1980:60) has written "[t]he ancient Đa Bút residents domesticated buffaloes and cows but they let them free in the forest near their settlement. The ancient Cồn Cồ Ngựa inhabitants might have known how to raise pigs, buffaloes and cows. The exploitation of natural food sources through hunting and gathering was still appreciated." This preliminary conclusion has since found support in newer research on faunal assemblages from the later site of Man Bac (Sawada, Thuy and Tuan 2011), during which the slow transition to agriculture had begun but broad-spectrum hunting and gathering continued.

Comparison of spore and pollen samples from the Đa Bút type-site itself with those from Côn Cổ Ngựa and Làng Còng suggests that their environments were similar, and furthermore that the occupation of all Đa Bút sites date approximately to the Middle-Late Holocene. The high percentage of Poaceae at a depth of $0.8 \mathrm{~m}$ within core samples suggests the possibility of initial wild plant cultivation at this time. It is impossible to identify which plants were cultivated by Đa Bút Period populations themselves, however the sudden appearance of floral pollen of species not known from core strata corresponding to the Hoabinhian or Bacsonian Periods might indicate the appearance of cultivars, but not rice, which reached Southeast Asia no earlier than 4,000BP, possibly in conjunction with millet in some regions of Southeast Asia (Bellwood 2011; Weber et al. 2010).

The archaeobotanical evidence from wild plant species (recovered in the form of pollen or spores from sediment cores) suggests primarily that inhabitants of Đa Bút Period sites settled within a freshwater marsh ecosystem, as well as along coastal plains or in limestone valleys. Exploiting all of these environments provided access to faunal and floral resources native to tropical forests, karst limestone outcrops, rivers, lagoons, deltaic marshes, and brackish-water estuaries. 
Table 1. Radiocarbon dates from Đa Bút Period sites.

\begin{tabular}{|c|c|c|c|c|}
\hline Ordinal No. & Sample codes & Sample depths & Lab. codes & Results \\
\hline 1 & ĐB86.II & Đa Bút $(0.6 \mathrm{~m})$ & Bln.3507/I & $5,710 \pm 60 \mathrm{BP}$ \\
\hline 2 & ĐB86.II & Đa Bút $(0.6 \mathrm{~m})$ & Bln.3507/II & $5,810 \pm 60 \mathrm{BP}$ \\
\hline 3 & ĐB86.II & Đa Bút $(0.8 \mathrm{~m})$ & Bln.3508/l & $6,390 \pm 60 \mathrm{BP}$ \\
\hline 4 & ĐB86.II & Đa Bút $(0.8 \mathrm{~m})$ & Bln.3508/II & $6,400 \pm 60 \mathrm{BP}$ \\
\hline 5 & ĐB86.IV & Đa Bút $(1.2 \mathrm{~m})$ & Bln.3510/l & $6,430 \pm 60 \mathrm{BP}$ \\
\hline 6 & ĐB86.IV & Đa Bút $(1.2 \mathrm{~m})$ & Bln.3510/II & $6,540 \pm 60 \mathrm{BP}$ \\
\hline 7 & ĐB71.HA & Đa Bút $(0.7 \mathrm{~m})$ & Bln.1407 & $6,095 \pm 60 \mathrm{BP}$ \\
\hline 8 & ĐB86 & Đa Bút $(1.2 \mathrm{~m})$ & Bln.3059 & $6,540 \pm 60 \mathrm{BP}$ \\
\hline 9 & 01BT(L1)TS & Bản Thủy (L1) & HNK-89 & $5,000 \pm 95 \mathrm{BP}$ \\
\hline 10 & 01BT(L1)TS & Bản Thủy (L1) & HNK-93 & $5,020 \pm 95 \mathrm{BP}$ \\
\hline 11 & 01BT(L2)TS & Bản Thủy (L2) & HNK-90 & $5,560 \pm 95 \mathrm{BP}$ \\
\hline 12 & 01BT(L2)TS & Bản Thủy (L2) & HNK-94 & $5,860 \pm 95 \mathrm{BP}$ \\
\hline 13 & $01 \mathrm{CCN}(\mathrm{L} 2) \mathrm{TS}$ & Cồn Cổ Ngựa (L2) & HNK-88 & $5,520 \pm 95 \mathrm{BP}$ \\
\hline 14 & $01 \mathrm{CCN}(\mathrm{L} 2) \mathrm{TS}$ & Cồn Cổ Ngựa (L2) & HNK-95 & $5,140 \pm 95 \mathrm{BP}$ \\
\hline 15 & $91 \mathrm{LCH} 3(\mathrm{C} 2)$ & Làng Còng $(0.7-0.8 m)$ & HCMV02/93 & $4,850 \pm 80 \mathrm{BP}$ \\
\hline 16 & 91LCH3(C2) & Làng Còng (1 m) & HCMV01/93 & $4,900 \pm 80 \mathrm{BP}$ \\
\hline 17 & 77GTH1 & Gò Trũng (0.6m) & Bln-2090 & $4,790 \pm 50 \mathrm{BP}$ \\
\hline 18 & 07HSH1L5 & Sáo Cave & HNK-358 & $9,170 \pm 105 B P$ \\
\hline 19 & 07HSH1L3 & Sáo Cave & HNK-373 & $9,060 \pm 125 \mathrm{BP}$ \\
\hline 20 & 07HSH1L3 & Sáo Cave & HNK-359 & $8,740 \pm 85 \mathrm{BP}$ \\
\hline 21 & 07HCH1L8 & Cò Cave & HNK-363 & $3,890 \pm 80 \mathrm{BP}$ \\
\hline 22 & 07HCH1L12 & Cò Cave & HNK-364 & $3,790 \pm 110 \mathrm{BP}$ \\
\hline 23 & 07HCH1L8 & Cò Cave & HNK-362 & $3,730 \pm 70 \mathrm{BP}$ \\
\hline 24 & 07HCH1L5 & Cò Cave & HNK-360 & $3,540 \pm 65 \mathrm{BP}$ \\
\hline
\end{tabular}

\section{MORTUARY AND BIOARCHAEOLOGY \\ Mortuary Archaeology}

The funeral rituals of the Đa Bút culture inhabitants are diverse between sites, but the most common burial form observed is that the deceased were buried sitting down, with folded legs. They were interred in round grave pits that are $0.60-0.70 \mathrm{~m}$ in diameter and $0.50-0.80 \mathrm{~m}$ deep. The arms and legs were folded and aligned vertically or on a slight upward slope, with the knees adjacent to the skulls. The wrists and ankles remain in standard anatomical position, but in a cross-legged sitting posture. This pattern is indicative of primary burials, without rearrangement of the bones. There are also some graves with skeletons placed in a sitting posture found at the Cồn Cổ Ngựa site itself, and they are disarticulated compared to standard anatomical position. The skulls are frequently observed to have become disarticulated and settled in between the two groups of limbs, or to have drifted to one side. In addition to this form of interment, some burials reveal the deceased to have been laid on their sides with legs folded up to the hip, or in a supine position with outstretched arms and legs.

In addition to single primary interments, double or triple burials are also known. There are three double-burials, with the deceased all being male. One triple burial includes two males and a female (Tấn 1990: 87). This burial might have belonged to a family, the female is approximately 25-30 years old and the two males are approximately 40-50 years old (Oxenham 2000; Parker 1998; Vinh 1991). Burials have been recovered at various depths, which demonstrates that the Đa Bút residents buried the deceased directly within their settlement sites. All burials so far recovered have come from high-density cemeteries: 14 graves found within $100 \mathrm{~m}^{2}$ at the Đa Bút site itself, two graves within $6 \mathrm{~m}^{2}$ at Bản Thủy, and 46 graves with 101 skeletons within $228.5 \mathrm{~m}^{2}$ at Cồn Cổ Ngựa during the 1980 excavation season. Recent re-excavation in 2011 and 2013 has more than doubled the total number of burials known from this site (Figure 3). 
At Cồn Cổ Ngựa, there is also a collective burial containing 50 individuals, including 20 males and 22 females (Figure 4). Most of them date between 25 and 36 years old; subadults are rare in this feature. When it was found, its border was ovoid, $7 \mathrm{~m}$ long, $5 \mathrm{~m}$ wide, with stones lining its edges, and all the deceased were buried at the same time, which might be due to an epidemic (Tấn 1990: 87; Vinh 1982a: 18). Other scholars have hypothesized that the reason for so many simultaneous deaths was a "deluge," when the mid-Holocene marine transgression reached its peak, a flash flooding event could have inundated a village. Tentative evidence for this is that the skeletons in this mass grave were haphazardly arranged; many of them overlapping each other without pattern. Most of the cemetery was uncovered underneath an alluvial layer, and many individuals were not arranged in the common sitting posture discussed above (Vinh 2003). It is not clear whether they died directly in a flood or indirectly in an epidemic caused by changing disease vectors as sea-level rise altered the estuarine ecosystem from which many food resources would have derived.

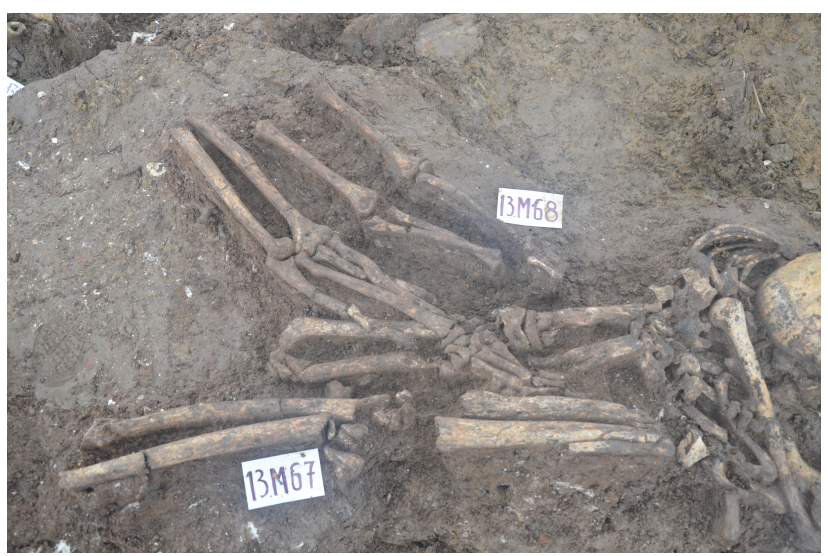

Figure 3. Double burial uncovered at the Côn Cổ Ngụa site in 2013. Photo by Trinh Hoang Hiep.

In terms of burial direction, $90 \%$ of the skeletons recovered from Côn Cổ Ngựa during the 1980 excavation face east or southeast; just $10 \%$ face west or northwest. The east is the direction of the sunrise and sea, which may relate to reverence for solar or sea deities, or have a more benign explanation (Tấn 1990: 88). Despite a primarily marine-oriented economy and subsistence economy, some burials were accompanied by items both marine and terrestrial in origin, such as ash, grinding pestles, shell ornaments, ceramics, deer horns, pig canines and sometimes pieces of red ochre.

There are many opinions in regards to the funeral rituals of Đa Bút Period populations. As the density of burials and the number of the deceased recovered from several of the open-air cemetery sites are relatively high, Patte in his initial work questioned if people may have had issues with the smell of decomposition. According to him, some of the dead had been defleshed and dried in order to prevent unpleasant aromas from decomposition, and then the bones were painted with red ochre and left for 2-3 years before reburial underground (Mansuy and Colani 1925). This explanation might be suitable in some cases, especially in regards to those burials in which several bones were burned, smoke-stained, missing altogether, disordered due to secondary burial, or exhibiting chipping or cut-marks. This is especially true in the case of Côn Cô Ngựa and Đa Bút (Vinh 1991; Parker 1998).

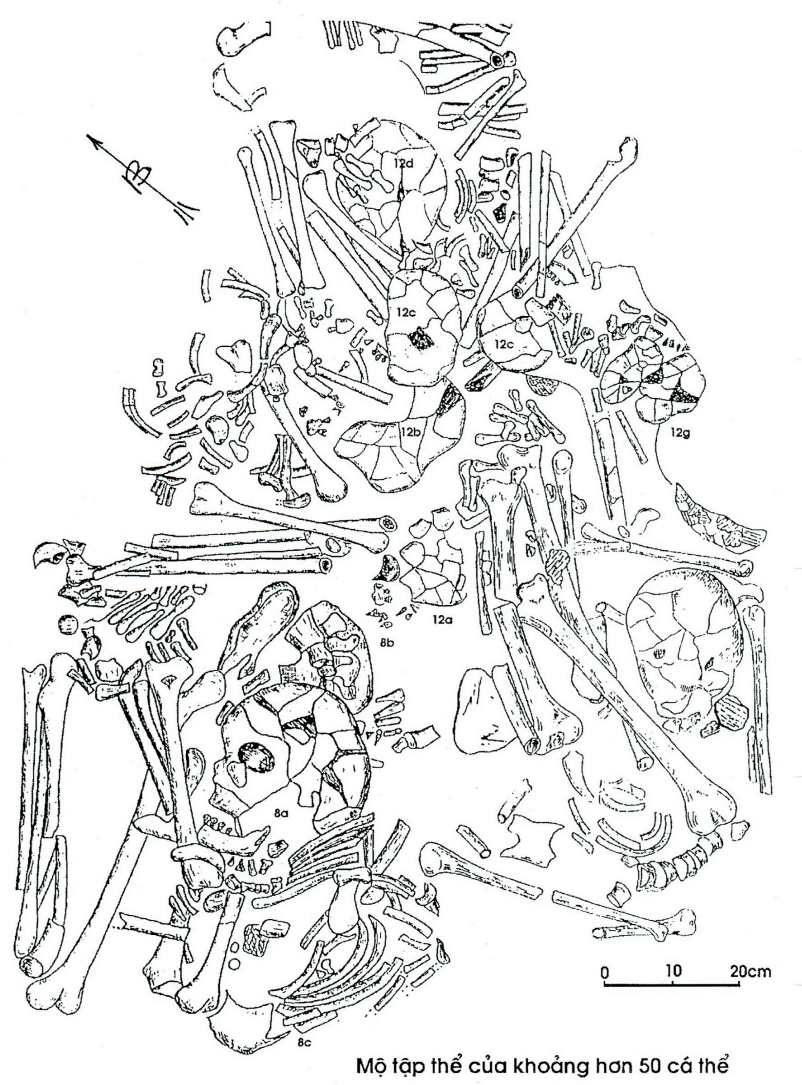

Figure 4. Collective burial from the Côn Cổ Ngụa site, Thanh Hóa province (Bùi Vinh 2003).

In regards to explanations behind the sitting posture frequently encountered in Đa Bút burials, the principles of archaeothanatological research could suggests that the dead were interned as bundle burials, or placed in large constricting baskets (Duday et al. 2006; Willis and Tayles 2009; Harris and Tayles 2012). However, this approach to burial recording has yet to be applied to any Đa Bút assemblage. Unfortunately, no fibrous artifacts have survived. Numerous prehistoric and historic cultures throughout the world have buried their dead in sitting postures (e.g. Guerrero et al. 2009; Richter et al. 2010; Vickers 1947). In Vietnam, this custom first appeared during the Hòa Bình Period (evident at the sites of Đắng Cave, Thâm Hoi Cave and Chùa Cave) and continued during the Quỳnh Văn Period, but increased in frequency during the Đa Bút Period. The phenomenon of folding a corpse before burying it might originate from the belief that burying the deceased underground is the symbolic of a fetus in the mother's womb; it is also the posture said to evoke eternal rest. Others have postulated that a folded 
corpse is easier to transport to the cemetery; it saves space in the cemetery and is less laborious for those who arrange the deceased. Patte assumed that "the action of tying the corpse before burying it originates from the fear that the dead (ghost) would return to harm those who are living" (Mansuy and Colani 1925; Patte 1928).

\section{Physical Anthropology and Biodistance Analysis}

In 1932, Patte (the first to osteologically assess skeletons from any Đa Bút site) analysed two skulls from the Đa Bút site itself, and hypothesized that they both represented a Melanesia phenotype, similar to that proposed for a Bắc Sơn Period skull from the site of Pho Bình Gia (Lạng Sơn Province) by Mansuy (Patte 1928: 57). In 1965, Patte changed his opinion and proposed that the Đa Bút populations appeared to have general phenotypic features characteristic of Papuan, Australoid and Melanesian people, but with smaller mandibles (Patte 1936: 121). More recent work, discussed below, has much more firmly established that Đa Bút populations represent the last genetically 'pure' Austro-Asiatic inhabitants in northern Vietnam, before widespread gene flow and hybridization occurred during the Neolithic Demographic Transition (Bellwood and Oxenham 2008).

In 1963, in a study of the Đa Bút Period skull referred to as ĐB3, Nguyễn Duy hypothesized that "the Đa Bút inhabitants belonged to the Australoid-Mongoloid races" (Cường 2003). In a more recent study of the four skulls recovered from the Đa Bút type site (including two labeled 26ĐBM1 and 26ĐBM2, now kept in the Museum of Vietnamese History), Thủy stated that "skull 26ĐBM1 is narrow, with a small front, so it has Melanesian characteristics. However, the standard skull top is five-sided and tower shaped indicates an Indonesian factor. On the other hand, 26ĐBM2 looks like a house roof, with a round occipital bone. It is difficult to distinguish between Melanesian and Indonesian" (Thủy 1999: 5).

Even more recent studies of regional population history have occasionally included the Đa Bút Period assemblage of Côn Cổ Ngựa, as it represents the largest and best preserved, and to date, best understood skeletal assemblage from the time period (e.g. Oxenham 2000; Huffer 2012; Parker 1998; Vinh 1991; Khoa 1979). Specifically, the Cồn Cồ Ngựa population has been phenotypically and morphometrically compared to later Southeast Asian Metal Age assemblages, East Asian populations, historic and modern samples and, recently, the Neolithic assemblage of Man Bac (e.g. Matsumura 2006; Matsumura and Hudson, 2005; Matsumura et al. 2008b, 2001; Pietrusewsky 2006; Matsumura et al. 2010). In general, the research above compares large batteries of craniometric, cranial nonmetric, odontometric, and dental nonmetric traits, either singly or in combination, and uses divergence statistics to quantify the total degree of difference between populations, revealing diachronic or synchronic genetic variation.

The majority of this research supports marked genetic and phenotypic differences between the Late Hoabinhian and Metal Age populations of the region, with the Cồn
Cổ Ngựa assemblage clustering with other Palaeolithic Hoabinhian samples throughout Southeast Asia. Metal Age aggregate samples (and the majority of the Neolithic Man Bac population), on the other hand, repeatedly cluster with prehistoric East Asian agriculturalist populations dating to the late Neolithic onwards, modern East Asian populations, and modern mainland Southeast Asian population; regardless of the specific type of skeletal or dental data used. All such evidence continues to support what is termed the 'two-layer hypothesis' as an explanatory model of Southeast Asian prehistory (e.g. Matsumura et al., 2008b), in-line with Asia-wide models of sinodonty vs. sundadonty originally put forth by Turner (1990). Only the very recent analysis of late prehistoric Cambodian populations from Phum Snay (Matsumura et al. 2010) has begun to reveal greater population admixture in later prehistory, at least in northwest Cambodia. In the case of Northern Vietnam, however, the evidence suggests that the large-scale population history of the region is by now established.

Stature estimates for Đa Bút males and females are approximately $1.65 \mathrm{~m}$ and $1.5 \mathrm{~m}$ respectively. The females have more evidence for tooth decay than males, but overall better oral health and less frequent dental or osseous pathology when compared to aggregate Metal Age populations (Oxenham 2000, 2006; Oxenham et al. 2008). Incisors and canines show less severe tooth decay, while the larger molars show greater frequency of caries, calculus, and periodontal disease. The occasional instances of trauma and osseous pathology (primarily periostitis) have also been noted (Oxenham 2000). A preliminary study of palaeodiet using stable isotopes of carbon and nitrogen, and the $\mathrm{Ba} / \mathrm{Sr}$ (barium/strontium) ratio has also been carried out; comparing a Cồn Cổ Ngựa subsample to an aggregate Metal Age population from Nui Nap (Bower et al. 2006). Results indicated more reliance on marine foods and less of a contribution from plants with $\mathrm{C}_{3}$ photosynthetic pathways, such as rice, compared to the Metal Age. In addition, strontium isotopic analysis of Côn Cổ Ngựa tooth enamel (Huffer 2012) suggested that at least a few individuals, predominately male, were born outside the community.

More recent discoveries of Đa Bút Period burials at the Bản Thủy site are described in Vinh (2003). Two burials buried one meter apart from each other and at the same depth were interred in a sitting posture with folded legs. Grave goods accompanying burial M1 include one pestle and two grinders. Burial M2 contains one grinder, three pestles and a fragment of a fully ground axe. The skeleton in burial M1 is of a female aged approximately 55-60 years, while M2 is also female, but aged approximately 2024 years. One of the 1979-1980 burials from Đa Bút belongs to a female aged approximately 30-40 years old, with a fairly thick cranial vault and medium-sized teeth (Cường 2003). Incidents of caries, periodontal disease, calculus, periostitis and occasionally severe ante-mortem trauma are relatively frequent, and yet most adults lived well into middle age. 


\section{MATERIAL CULTURE}

\section{Lithic Artifacts}

Lithic tools and edge-ground axes and adzes represent the majority of the material cultural assemblage frequently recovered from Đa Bút excavations (Figure 5). Axes total 179 individual artifacts. Based on the characteristics of material and manufacturing techniques, they can be divided into three types based on their increasing degree of grinding: 97 with ground edges, 52 ground to the body, and 34 completely ground specimens.

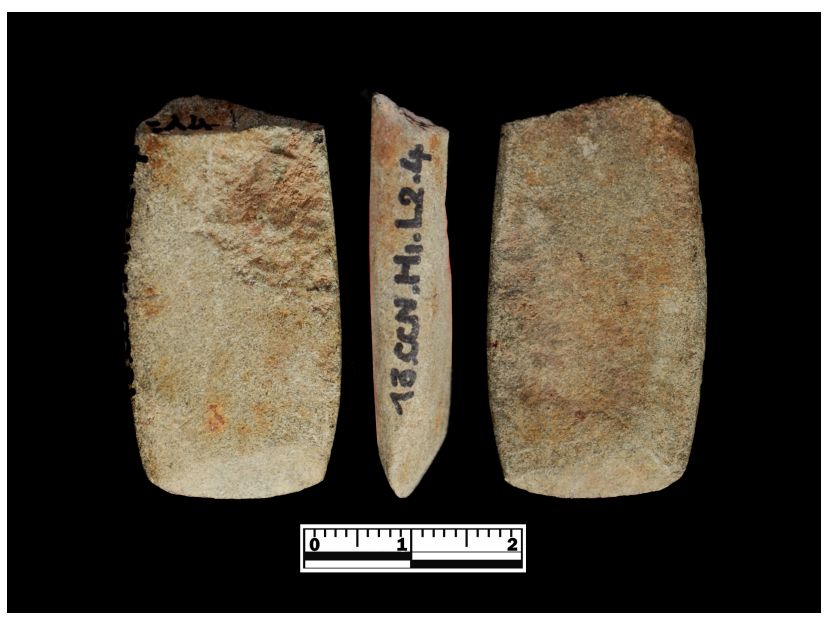

Figure 5. Polished stone axe recovered from the Côn Cổ Ngụa site in 2013.

Axes with ground edges include 97 artifacts, which account for the greatest portion of all the axes recovered from Đa Bút Period sites to date (44 items from the Đa Bút site, 47 items from Cồn Cổ Ngựa, two from the Gò Trũng site and four from Đồng Vườn). No such tools were recovered at the Làng Còng site. Different from their Bắc Sơn Period counterparts, these axes with ground edges from Đa Bút contexts are usually large, thicker and made from river pebbles. Axes ground to the body include 52 items. The bodies of these axes were ground but all traces of chipping did not completely disappear. In terms of a technological standard, this type is more refined than edge-ground axes, but not as much as axes with entirely ground edges. Compared to edge-ground axes, these are smaller and more standardized, normally flaked to remove the entire cortex. There are three sub-categories designated by shape in cross-section: ovoid, near-trapezoidal and U-shaped. This category of hand-axe (all three subcategories) appears in all Đa Bút Period sites, but have most frequently been recovered at Cồn Cổ Ngựa (32 items).

Fully ground axes are represented by 34 items, a relatively small quantity. Their manufacturing technique, however, exhibits great skill, with precise and symmetrical shape and a small size on average (5-6cm long, 3$4 \mathrm{~cm}$ wide and $1-1.5 \mathrm{~cm}$ thick). In terms of shape, most are trapezoidal, with rounded corners, convex sides and oval or lens cross-section (27 items). Some are nearly rectangular, sometimes also with a rectangular cross-section.
Most of them are made of schist, and examples have been recovered from every Đa Bút site. However, most of them were found at Gò Trũng, followed by Côn Cổ Ngựa and Làng Còng, with Đa Bút itself containing the fewest.

\section{Chipped tools}

This category includes 102 artifacts from sites including Làng Còng (59), Đa Bút itself (30), Cồn Cổ Ngựa (11) and Gò Trũng (2). They are varied in form and manufacturing technique. Some of them were made of intact pebbles, with limited traces of chipping, forming a partially retouched edge at the narrow end of the pebble, running along the length of the pebble with both edges (referred to in Patte $(1932 ; 1936)$ as 'mandrels'). Some of the chipped stone tools are reminiscent of those from the Son Vi Period. These tend to be chipped around their entire perimeter, sometimes deeper along one side, forming almond and discoid shapes, as well as shorter forms reminiscent of those from Hòa Bình Period sites. A few waste flakes were also recovered at Làng Còng, left over from the tool making process

Twenty-three artifacts can be categorized as draft axes, which normally exhibit thick, roughly chipped edges, so it is impossible to use them for chipping if they are not already ground. Some of them are ovoid, or in the shape of an isosceles trapezoid, similar to the most common forms of fully ground axe. Only one awl has been recovered from a Đa Bút Period site to date, specifically from Gò Trũng very near the stratigraphic interface with the sterile basal layer. It was made of schist, smoothly ground, tapered at one end but not pointed; the other end was ground into a pointed awl. Its body is $7.5 \mathrm{~cm}$ long, $2 \mathrm{~cm}$ wide and $1 \mathrm{~cm}$ thick. Seven chisels in total were recovered from Đa Bút contexts at Gò Trũng. These are made from long, flat pebbles with blades ground evenly along both sides. Their average size is approximately 7 $9 \mathrm{~cm}$ long, $1-1.5 \mathrm{~cm}$ wide, and $1 \mathrm{~cm}$ thick. Other forms of chisel are distinguishable by having round, thick handles. Six tools classified as saws have also been recovered, all made of sandstone, with straight blades ground evenly along both sides. They are $5-6 \mathrm{~cm}$ long and may have been used to saw bones, horn or to form grooves on fishing net sinkers for tying ropes.

Net sinkers include 79 such artifacts made of stone, excluding 28 unfinished items, and eight made of terracotta recovered from the Gò Trũng site (Figure 6). Excavations in 2000 at the Làng Còng site recovered seven stone net sinkers. As a result, the total number of these artifacts found in Đa Bút Period sites is now 112, including 105 items from Gò Trũng, eight from Làng Còng, four from C ôn Cổ Ngựa and one from the Đa Bút site. Most of these were made of schist and their most common form resembles the fruit of the Elaeagnus latifolia tree, being approximately $4-5 \mathrm{~cm}$ long and $3-4 \mathrm{~cm}$ wide, ground and grooved for tying into a net with rope. A few subcategories exist; specifically, net sinkers with one groove, two grooves (cruciform), and grooves at the two margins. Apart from the recovered net sinkers discussed above, two unique stone net sinkers (one from Đa Bút site and 
the other from Làng Còng) were drilled to allow a cord to be passed through.

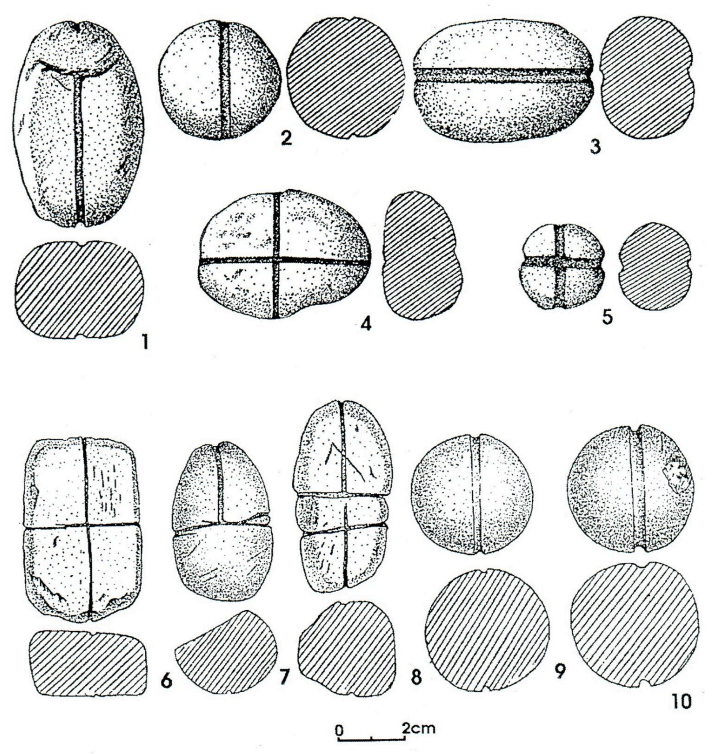

Figure 6. 1-8. Stone net-sinkers; 9-10. Clay net-sinkers from the Gò Trüng site, Thanh Hóa province (Bùi Vinh 2003).

Six artifacts (two from Cồn Cổ Ngựa and four from Gò Trũng) that resemble small discs with a central perforation have been recovered from Đa Bút Period sites. All of them are made of soft schist, circular, $4-6 \mathrm{~cm}$ in diameter, $1 \mathrm{~cm}$ thick, smoothly ground, with a drilled hole (approximately $0.6 \mathrm{~cm}$ ) in the centre. As to their function, it is possible that they might be earrings, or spindle-whorls, or have another use entirely, and that that they represent unique Đa Bút Period artifacts.

Two artifacts classified as stone hammers were recovered from Gò Trũng. They are cubic-rectangles with one wide end and one narrower end. They were finely ground and made of hard and heavy sandstone. One of them is intact, approximately $12.5 \mathrm{~cm}$ long, $4.1 \mathrm{~cm}$ wide, and $1.2-$ $3.2 \mathrm{~cm}$ thick. One stone knife was recovered from the Đa Bút site, made of a pebble cracked lengthwise to form a thin blade that was finished via pressure flaking. It has a thick back, so its morphology suggests possible use as a hammer stone.

Twenty-six grinding stones have also been recovered from Đa Bút contexts. They are commonly made of sandstone, with an average size of $10 \mathrm{~cm} \times 8 \mathrm{~cm}$. Traces of grinding activity are present on the concave surface; while some others are boat-shaped or ovoid. Many contain traces of grinding along both sides. In addition, nineteen mortars have been recovered; thirteen have concavities that indicate frequent use; some with deep indents and some ground on both sides until they have worn through. Six of the mortars discovered include boat-shaped traces of grinding, similar to, for example, manos and metates frequently recovered from prehistoric and early historic sites in the southwestern United States (e.g. Schlanger 1991;
Adams 1993). Therefore, it is likely that they were used for food processing.

One hundred and eighty artifacts of various forms and sizes are categorized as pestles. They are made of larger pebbles, with use-wear traces on one or both convex ends. Some of them are very small, just $3 \mathrm{~cm}$ long and $2 \mathrm{~cm}$ wide. The macroscopic use-wear itself can also take various forms: convex round, flat, or lop-sided (when the pestle was used for grinding tubers to extract powder). In particular, at Gò Trũng there are round and flat pestles resembling wheels, which were most likely paired with the boat-shaped mortars. Anvils and beaters are represented by forty-one artifacts, all of which are made from flat, round pebbles approximately the size of an orange $(6-7 \mathrm{~cm}$ in diameter, $3-4 \mathrm{~cm}$ thick). On one or both sides, there is a convex groove approximately $1-2 \mathrm{~cm}$ deep. They appear in all sites of the Đa Bút Period, with Gò Trũng containing the most (a total of fifteen). Forty-six hammering stones are also known from Đa Bút sites. Initially, they are oval, cylindrical, and round pebbles, but they become pitted on the entirety of their bodies due to their use in the flaking or retouching process. Finally, four otherwise nondescript, uncategorized stone artifacts (three from Đa Bút and one from Làng Còng) are known. They exhibit flat surfaces on which there are hollow smooth traces of some type of grinding activity, with the grooves being on average $2 \mathrm{~cm}$ in diameter (Ngọc 2009).

\section{Bone and Shell Artifacts}

Bone and shell artifacts constitute a significant component of a typical Đa Bút Period assemblage. There is a chisel made of part of a dear horn with one end ground to form a blade and another chisel made of a fragment of an animal tibia with one end ground into a point. Mollusk shells were used for making tools or ornaments. At the Đa Bút site, for example, large oyster shells were used for keeping red ochre and thick oyster shells were ground to form blades. Sea-snail shells pierced with a string have also been recovered, likely worn as a necklace. Blood clamshells might also have been brought back from sea and used for some other purposes, not necessarily for food.

\section{Earthenware and Terra-Cotta Ceramics}

Ceramics represent a crucial component of the Đa Bút Period material cultural assemblage, which enable us to study the advent and early development of ceramics in Vietnamese prehistory. At every Đa Bút Period site, the materials for making ceramics are the same; coarse clay mixed with a high quantity of grit and pebbles. Sometimes, the clay matrix is also tempered with quartz grits that are $1-2 \mathrm{~mm}$ in size. In particular, some base sherds contain a much higher percentage of this grit compared to body or rim sherds. On average, Đa Bút Period ceramics are $0.7-0.8 \mathrm{~cm}$ thick at the body wall, $0.9 \mathrm{~cm}$ thick at the neck, and $1-1.6 \mathrm{~cm}$ thick at the base. Some are as thick as $2.6 \mathrm{~cm}$ at the shoulder. However, some early forms of thinner and finer ceramics were also manufactured. Notably, Đa Bút Period ceramics are currently considered the 
thickest vessels known from Vietnam to date (Rispoli 2007) (Figure 7).

There are three vessel forms, defined by the vessel wall thickness: coarse, medium and thin. The matrix of the coarse vessels is over $1 \mathrm{~cm}$ thick, medium between $0.6-1 \mathrm{~cm}$ thick, and thin under $0.6 \mathrm{~cm}$. Ceramic morphology during the Đa Bút Period consists solely of globular pots with high shoulders, slightly wasted, vertical necks, flared mouths, and flat rims. The most common feature of Đa Bút Period ceramics is that the entire rim exhibits traces of paddle-impression, with or without distinct designs.

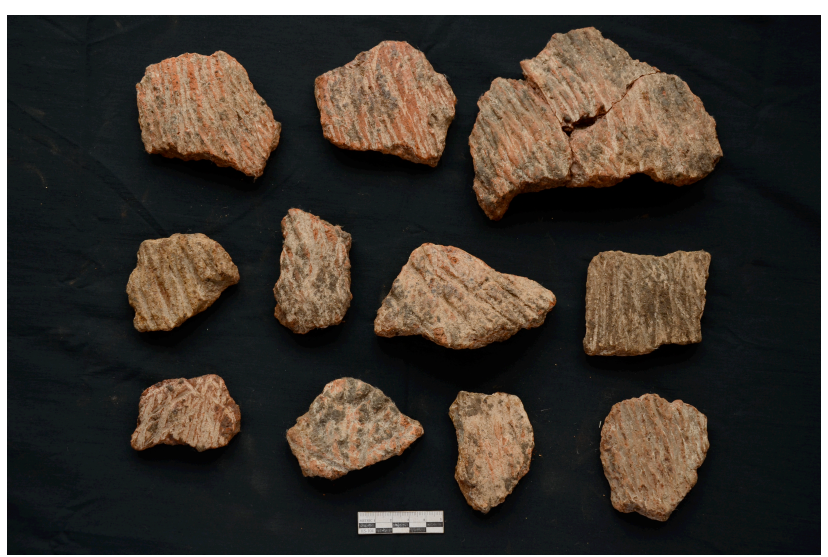

Figure 7. Pottery recovered from the Côn Cổ Ngụ̣a site in 2013.

Đa Bút Period ceramics exhibit uniform and simple decorative motifs on their bodies, divided into four primary types. Firstly are those sherds exhibiting paddleimpressions made with a grooved beater, resembling matlathes. These are the finest and most regular designs seen on Đa Bút Period ceramics. Secondly, there are sherds with paddle-impressions made from beaters covered by untwisted rope. The grooves made in this manner often contain traces of both scraping and beating. From the beating traces, it seems likely that the beaters used were tubes rolled with cords. The cordage used is single, straight and as hard as rattan or bamboo, as opposed to the softer, twisted cordage that became increasingly common during later periods.

Thirdly, there are paddle-impressed sherds made with beaters covered in tightly twisted cordage. The cordmarking found on most Đa Bút sherds is of a refined, not rudimental, quality. It can be surmised that the potter initially used a soft cord rolled around a beater. During rotation of the beater around the vessel, the cord automatically twisted tighter to some extent, and then the technique of making cord designs by twisting two single strands together appeared. Finally, numerous rim sherds of smaller vessels exhibit traces of having been beaten with an unmodified (plain) beater. These vessels have both flared and straight mouths without necks, resembling bowls. In terms of vessel form, this type is not as complicated as those vessels with necks.

In regards to the specific techniques used to paddleimpress Đa Bút vessels, two stylistic categories have been identified. The first motif was applied using beaters wrapped with tightly twisted cordage. Blows were delivered to the wet clay in a slightly slanting direction relative to the axis of the vessel body. This technique was the most popular means by which to decorate vessels (assessed from percent frequency data). The other technique used was direct beating of the body using mainly grooved, but otherwise unadorned, beaters. Either of these methods more or less formed mat-lathe pattern designs, indicated by the fact that these motifs account for $90 \%$ of all known examples (Dung 2003).

Đa Bút Period ceramics were all modeled by hand with the use of anvils and beater. Beginning with the raw clay mass, which would have matched the size and volume of the intended vessel, the potter used an anvil to beat the clay mass until it became hollow. Then, he/she applied upward strokes along the entire height of the vessel while shaping it. The next stage is completing the vessel body itself. The vessel would have been positioned vertically for forming the vessel walls by striking the outer surface with the anvil, and a pebble held against the inner wall for support.

In addition to the gradual increase in quantity of ceramics manufactured during the Đa Bút Period, certain changes are noticeable in regards to manufacturing technique and decoration motifs. While only coarse and thick ceramics with cord-marked designs were recovered from the Đa Bút and Bản Thủy sites, there are many thin, fine ceramics with finer grooved designs found at Côn Cổ Ngựa (Vinh 1991; Viet 2005, 2007). At the Gò Trũng site, there are many ceramics found in the upper stratum with thicknesses ranging from $0.4-0.5 \mathrm{~cm}$ thick, as well as thinner, grooved sherds approximately $0.3-0.4 \mathrm{~cm}$ thick. Overlap between ceramic types within the same stratigraphic layer is unusual for Đa Bút Period sites. Therefore, it can be argued that Đa Bút ceramics appeared early, perhaps as early as 6,000 BP, and that the Đa Bút interaction sphere is one of the earliest ceramic producing centres in Vietnam.

The Southeast Asian late Paleolithic to early Neolithic transition is poorly dated, especially in Vietnam and southern China (Higham 1989; 2002). There are only a few sites that clearly demonstrate post-Hoabinhian 'Neolithization;' specifically the sites of Đa Bút and Cái Bèo, numerous sites of the Quỳnh Văn Culture in Vietnam, or Ding Shi Shan Culture sites in Guangxi (discussed below). Ceramics appear relatively late in island Southeast Asia; no earlier than c. 5,000 BP. Ceramics from mainland Southeast Asia, such as the Khorat Plateau in Thailand, also first appear in cave strata dating to approximately c. 6.500-6,000 BP (e.g. Anderson 2005).

In Vietnam, early ceramic manufacture began at least c. 6,500BP, based on shell AMS dates from throughout the stratigraphic column at the Đa Bút site itself (Vinh 1991: 128). However, recent excavations at numerous cave sites within the Tràng An World Heritage region, such as Vàng Rock Shelter, Ốc Cave, and the upper layer of Mòi Cave, have also revealed rich ceramic deposits. At Sáo Cave (Ninh Bình Province) near Tràng An, coarse 
potsherds similar to those found at Đa Bút itself have been suggested to date to $c .9 .000 \mathrm{BP}$, but the clay itself was not dated. Therefore, the ceramics recovered from Tràng An region sites tentatively date to $c .7 .000-9.000$ BP. If legitimate, these would be the earliest ceramics known so far from Southeast Asia (Đối et al. 2012: 3347).

At Zengpiyan Cave (Guangxi, China), ceramics have been recovered from strata dating to $c$. 11,000-12,000 BP (Zhang et al. 2011), but the clay itself was not dated. These sherds appear only vaguely similar to ones found at Tràng An cave sites, or Đa Bút itself, because they were manufactured by the coiling method and their external surface includes cord-marked designs as opposed to paddle-impression. Early ceramics from the shell mound sites of the Ding Si Shan culture in Nan Ning (Guangxi, China) are also dated to $c .9 .000-10.000 \mathrm{BP}$, with a later strata containing a Neolithic cemetery $(\mathrm{n}=331)$ dating to $c$. 8,000-7,000BP (Fu et al. 1998; Fu 2002).

The sherds recovered are also coarse and thick; their matrixes are mixed with quartz fragments, decorated with cord marking or basket-impressed designs on their external surface, made by the coiling method, and usually exhibit applique bands directly under the rim. In Vietnam, cord-marked ceramics or ceramics made by the coiling method normally occur later than those made by hand using pestles and anvils, as well as sherds with simple grooved designs made with pestles wrapped in tree-bark cordage, such as the archetypal Đa Bút ceramics. Therefore, it has recently been proposed that Tràng An and Đa Bút were independent centers of ceramic manufacture in the region (Nguyễn Gia Đối et al. 2012).

\section{FUTURE RESEARCH DIRECTIONS}

The Đa Bút Period encompassed the late Paleolithic Period in Vietnam. The latest excavations and analyses continue to confirm the absence of the typical stone tool assemblage characteristic of the Hoabinhian and Bacsonian Periods, the initial appearance of ceramics that are coarser and usually lacking in intricate geometric designs, the minimal occurrence of fully ground axes and the total absence of bronze until at least $c .3500 \mathrm{BP}$.

The date of the earliest deposits at the Đa Bút site itself is unknown because the samples analyzed to date do not come from the most basal strata in the profile. After calibration, it is still possible that date ranges for Đa Bút Period might span from $c .7,000-4,300 \mathrm{BP}$ as proposed by Bayard (1984). The latest date obtained so far, from the site of Cò Cave, if calibrated, indicates a terminus for the Đa Bút Period c. 4.000 BP (Miên and Hiệp 2009). However, the controversy surrounding the very early dates now reported from Tràng An area sites remains unresolved and is in need of much greater exploration and many more dates from in-situ material. For all aspects of Đa Bút prehistory, especially regarding subtle community-level differences in living conditions as understood from skeletal data and mortuary practices, more systematically excavated sites and mortuary assemblages are needed. New analysis of the skeletons from the 2011 and
2013 re-excavation of Con Co Ngua will be a big step in this direction.

Fundamentally, new research into Đa Bút Period lifeways could benefit most from more detailed investigations of topics other than chronology or material culture typologies. Most crucially, renewed effort to securely date the beginning and end of the period via additional ${ }^{14} \mathrm{C}$ dates from secure contexts; ideally derived from bone or dentine collagen from mortuary contexts (whenever possible). More detailed studies of ceramic and stone raw material source before and after the genetic diversification of Vietnam during the Neolithic Demographic Transition would better illuminate coastal-inland trade networks.

Collecting isotopic data for many more skeletons, especially oxygen and strontium, would allow a much more thorough understanding of migration patterns and dietary diversity between Đa Bút communities. Finally, the neardoubling of the MNI for the Cồn Cồ Ngựa assemblage will provide numerous opportunities to expand upon recent bioarchaeological work (e.g. Huffer and Oxenham in review), including the possibility of a much more refined study of variation in the Đa Bút "seated" burial pattern using state-of-the-art archaeothanatological methods (e.g. Harris and Tayles 2012; Willis and Tayles 2009). It is research such as this that will open up new windows onto daily life during this crucial time period; a time period for which the big-picture archaeological research discussed above has set the stage.

\section{ACKNOWLEDGEMENTS}

DH would like to thank Dr. Trinh Hoang Hiep, Dr. Alison Carter and Dr. Nam Kim for allowing him to participate in and contribute to an article in this special edition. He would also like to thank all friends and colleagues at the Vietnamese Institute of Archaeology for their constant support throughout numerous seasons of excavations and research over many years. THH would also like to extend thanks to Drs. Kim and Carter for organizing this volume and to all colleagues at the Institute of Archaeology past and present. Both authors would also like to thank the anonymous peer reviewers for helpful comments on earlier drafts.

\section{REFERENCES}

Adams, J.L. 1993. Toward understanding the technological development of manos and metates. Kiva 58: 331-344.

Anderson, D.D. 2005. The use of caves in peninsular Thailand in the Late Pleistocene and early and middle Holocene. Asian Perspectives 44: 137-153.

Bayard, D.T. 1984. A checklist of Vietnamese radiocarbon dates. Southeast Asian archaeology at the XV Pacific Science Congress, University of Otago Studies in Prehistoric Anthropology. Vol. 16. Dunedin

Bellwood, P. 2011. The checkered prehistory of rice movement southwards as a domesticated cereal-from the Yangzi to the Equator. Rice 4: 93-103.

Bellwood, P. 2008. Agricultural dispersals in mainland and island Southeast Asia. Symposium about the site of Man 
Bac (Ninh Binh province): Issues and discussion. Institute of Archaeology, Hanoi, Vietnam, 19th July, 2008.

Bellwood, P. and Oxenham, M. 2008. The expansions of farming societies and the role of the Neolithic demographic transition. The Neolithic demographic transition and its consequences. Springer: Netherlands, pp. 13-34.

Bower, N.W., Yasutomo Y., Oxenham, M.F., Nguyen, L.C., Nguyen, K.T. 2007. Preliminary reconstruction of diet at a Neolithic site in Vietnam using stable isotope and $\mathrm{Ba} / \mathrm{Sr}$ analyses. Bulletin of the Indo-Pacific Prehistory Association 26: 79-85.

Colani, M. 1927. "L'Age de la pierre dans la province de HoaBinh (Tonkin)", Mémoires du Service Géologique de L'Indochine, 14 (1).

Colani, M. 1928. Notice sur la préhistoire du Tonkin. I. Deux petits ateliers; II. Une pierre a cupules; III. Stations hoabinhiennes dans la région de Phu Nho Quan (Provice de Ninh Binh). Bulletin du Service Géologique de L'Indochine 17: 1-44.

Colani, M. 1938. Découvertes Préhistoriques dans les parages de la Baie d'Along. Institut Indochinois pour l'Etude de l'Homme 1: 93-96

Colani, M. 1939. Recherches préhistoriques en Baie d'Along., 14: 12-19. Cahiers de l'Ecole Francaise d'ExtrêmeOrient

Cường, N.L. 1996. Đặc điểm nhân chủng cư dân văn hóa Đông Sơn ở Việt Nam. Nxb KHXH, Hà Nội.

Cường, N.L. 2003. Di cốt người trong văn hóa Đa Bút. Khảo Cổ Học 3: 66-79.

Cường, N.L. 2003. Các nhóm loại hình nhân chủng ở Việt Nam và vấn đề ngu ồn gốc người Việt. Library of the Vietnamese Institute of Archaeology: 66-79.

Cường, N.L. Thủy, N.K. and Hưng, V. 1980. Di cốt người cổ ở Cồn Cổ Ngựa (Thanh Hóa). Nhũ̃ng Phát Hiện Mới về Khảo Cổ Họ Năm 1980, pp. 56-57.

Ding, Z.-L., et al. 2012. Origins of domestic dog in Southern East Asia is supported by analysis of Y-chromosome DNA. Heredity 108: 507-514.

Đối, N.G. and Lâm, N.T. 1992. Sưu tập đồ đá Làng Còng (Thanh Hóa). Những Phát Hiện Mới về Khảo Cổ Học Năm 1992, pp. 52-53.

Đối, N.G. and Sử, N.K. 2002. Báo cáo điều tra khảo cổ học Tam Điệp và Nho Quan (Ninh Bình). Tư liệu Viện KCH.

Đối, N.G. et al. 2012. Khai quật di chỉ mái đá Ông Hay ở Tràng An. Khảo Cổ Học 5: 70-78.

Duday, H., Cipriani, A.M. and Pearce, J. 2009. The Archaeology of the Dead: Lectures in Archaeothanatology, Vol. 3. Oxbow Books: Oxford.

Dung, N.K. 1979. Một số ý kiến về hoa văn trên đồ gốm văn hóa Đa Bút. Những Phát Hiện Mới về Khảo Cổ Học Năm 1979: 69-71.

Dung, N.K. 1983. Hai hệ thống gốm sớm trong thời đại đá mới Việt Nam. Khảo Cổ Hoc 1: 22-35.

Dung, N.K. 1984. Một chức năng trong các công cụ đá của văn hóa Đa Bút: chức năng cuốc. Khảo Cổ Học 1, 2: 53-55.

Dung, N.K. 2003. Nghiên cứu so sánh đồ gốm trong văn hóa Đa Bút. Khảo Cổ Hoc 3: 56-65.

Dỹ, N.D., Thuậnm, D.V. and Đạt, T. 1980. Phân tích bào tử phấn hoa ở Cồn Cổ Ngựa; vài nét về cổ địa lý ở vùng
Cồn Cổ Ngựa. Những Phát Hiện Mới vể Khảo Cổ Học Năm 1980: 62 - 65.

Fromaget J. 1941. L'Indochine Francaise, sa structure géologique, ses roches, ses mines et leurs relations possible avec la tectonique", Bulletin du Service Géologique de L'Indochine 25: 2 - 63.

Fu, X.G. 2002. The Dingsishan site and the prehistory of Guangxi, south China. Bulletin of the Indo-Pacific Prehistory Association 22: 63-72.

Fu, X.G. Li, X.W., Li, L., Zhang, L. and Chen, C. 1998. The excavation of Ding Si Shan site in Yongning, Guangxi. Archaeology Journal 11: 11-33

Guerrero, E., Molist, M., Kuijt, I. and Anfruns, J. 2009. Seated memory: New insights into Near Eastern Neolithic mortuary variability from Tell Halula, Syria. Current Anthropology 50: 379-391.

Hảo, N.V. 2000. Khai quật lần thứ hai di chỉ thời đại đá mới Làng Còng (xã Vĩnh Hưng, huyện Vĩnh Lộc, tỉnh Thanh Hóa), Tu Liệu Viện Khảo Cổ Học, pp. 10-16.

Hảo, N.V. and Chiến, N.T. 1979. Di chỉ Bản Thủy. Những Phát Hiện Mới vể Khảo Cổ Học Năm 1979, pp. 56-57.

Harris, N. and Tayles, N. 2012. Burial containers - A hidden aspect of mortuary practices: Archaeothanatology at Ban Non Wat, Thailand. Journal of Anthropological Archaeology 31: 227-239.

Higham, C.F. 1989. The archaeology of mainland Southeast Asia: from 10,000 BC to the fall of Angkor. Cambridge University Press: Cambridge.

Higham C.F. 2002. Early Cultures of Mainland Southeast Asia. Bangkok: River Books.

Huffer, D. 2012. The Ties that Bind: Population Dynamics, Mobility and Kinship during the mid-Holocene in Northern Vietnam. Unpublished PhD dissertation, The Australian National University, Canberra, ACT, Australia.

Huffer, D. and Oxenham, M. in review. Investigating activity and mobility patterns during the mid-Holocene in northern Vietnam. Forthcoming in Oxenham, M. and Buckley, H. (Eds). The Routledge Handbook of Bioarchaeology in Southeast Asia and the Pacific. Routledge Press: Oxford.

Hương, N.M. 2000. Kết quả phân tích bào tử phấn hoa di chỉ Làng Còng. Khai quật lần thứ hai Di chỉ thời đại đá mới Làng Còng, Tư Liệu Viện Khảo Cổ Học, pp. 32-35.

Hương, N.M. and Hải, P.V. 2002. Kết quả phân tích bào tủ phấn hoa di chỉ Bản Thủy, Thanh Hóa, Tư Liệu Viện $\mathrm{KCH}, \mathrm{pp}$. 24-32.

Khoa, N.D. 1979. Xung quanh những ý kiến về nhóm loại hình Indonesien và Nam Á. Khảo Cổ Hoc: 23-26.

Long, V.T. 1979. Di tích động vật ở di chỉ Đa Bút (Thanh Hóa) trong đợt khai quật 1971. Những Phát Hiện Mới về Khảo Cổ Học Năm 1979, pp. 54.

Long, V.T. 1980. Di tích động vật Cồn Cổ Ngựa (Thanh Hóa). Những Phát Hiện Mới về Khảo Cổ Học Năm 1980, pp. 60.

Long, V.T. 2000. Kết quả giám định di tích động vật di chỉ khảo cổ học Làng Còng (Thanh Hóa). Khai Quật Lân Thứ Hai Di Chỉ Thời Dại Dá Mới Làng Còng, Tư Liệu. Viện Khảo Cổ Học, Hanoi, pp.21-31.

Long, V.T. 2003. Người Đa Bút và môi trường động vật. Khảo Cổ Hoc 3: 80-87. 
Matsumura, H. 2006. The population history of Southeast Asia viewed from morphometric analyses of human skeletal and dental remains. In Oxenham, M.F. and Tayles, N. (eds.) Bioarchaeology of Southeast Asia. Cambridge University Press: Cambridge, pp. 33-58.

Matsumura, H., Dommett, K.M., and O'Reilly, D.J.W. 2010. On the origin of pre-Angkorian peoples: perspectives from cranial and dental affinity of the human remains from Iron Age Phum Snay, Cambodia. Anthropological Science 119: 67-79.

Matsumura, H. and Hudson, M.J. 2005. Dental perspectives on the population history of Southeast Asia. American Journal of Physical Anthropology 127: 182-209.

Matsumura, H., Cuong, N. L., Thuy, N.K., and Anezaki, T. 2001. Dental morphology of the early Hoabinhian, the Neolithic Đa Bút and the Metal Age Dong Son Cultural people in Vietnam. Zeitschrift fur Morphologie und Anthropologie 83: 59-73.

Matsumura, H., Oxenham, M.F., Dodo, Y., Domett, K., Cuong, N.L., Thuy, N.K., Dung, K., Huffer, D., and Yamagata, M. 2008b. Morphometric affinity of the late Neolithic human remains from Man Bac, Ninh Binh Province, Vietnam: Key skeletons with which to debate the 'two-layer' hypothesis. Anthropological Science 116: 135-148.

Mên, N.N. and Hảo, N.V. 1976. Quan hệ địa tâng của di chỉ Gò Mả Hờ và di chỉ Gò Trũng, Thanh Hóa. Nhũ̃ng Phát Hiện Mới vê Khảo Cổ Học Năm 1976, pp.72

Miên, D.T. and Võ, L.V. 2001. Vi cổ sinh (tảo Silic, trùng lỗ) Holocen và môi trường thành tạo trâm tích ở đồng bằng Thanh Hóa. Tap Chí Các Khoa Hoc vê Trái Đất 3: 33-41.

Miên, N.Q. and Vinh, B. 2003. Văn hóa Đa Bút trong tiến trình phát triển miên đồng bằng Thanh Hóa-Ninh Bình. Khảo Cổ Học 3: 31-44.

Miên, N.Q. and Hiệp, T.H. 2009: Về những kết quả đo tuổi C14 di tích Hang Cò (Ninh Binh), New Archaeological Discoveries in 1998. Social Sciences Publishing House, Hanoi: $133-135$

Nga, H.H. 2005. Không gian xã hội Đa Bút (trường hợp di chỉ, Cồn Cổ Ngựa). Khảo Cổ Học: 3-14.

Mansuy, H. 1909. Gisement préhistorique de la caverne de pho Binh Gia (Tonkin). l'Anthropologie 20: 20-40.

Mansuy, H. and Colani, M. 1925. Néolithique inferieur (Bacsonien) et néolithique supérieur dans le Haut Tonkin avec la description des crames du gisement de Lang Cuom. Mémoires du Service Géologique de L'Indochine 12: 47.

Ngọc, N.X. 2009. Văn hóa Đa Bút tiếp cận văn hóa học tiên sử, Luận án Tiến sĩ, Thư viện Viện Khảo cổ học.

Oxenham, M.F. 2000. Health and Behavior During the MidHolocene and Metal Period of North Viet Nam. Unpublished Ph.D. dissertation, Northern Territory University, Darwin, Australia.

Oxenham, M.F. 2006. Biological responses to change in prehistoric Viet Nam. Asian Perspectives 45: 212-238.

Oxenham, M.F., Matsumura, H., Domett, K., Thuy, N. K., Dung, N.K., Cuong, N.L., Huffer, D. and Muller, S. 2008. Health and the experience of childhood in late Neolithic Viet Nam. Asian Perspectives 47: 190-209.

Pang, J.-F., Kluetsch, C., Zou, X.J., Zhang, A.B., Lou, L.Y., Angleby, H., Ardalan, A., Ekstrom, C., Skollermo, A., Lundeberg, J., Matsumura, S., Leitner, T., Zhang, Y.P., and Savolainen, P. 2009. mtDNA data indicate a single origin for dogs south of the Yangtze River, less than 16,300 years ago, from numerous wolves. Molecular Biology and Evolution 26: 2849-2864.

Parker, K. 1998. The Early Neolithic Cemetery of Cồn Cổ Ngựa, Northern Vietnam: Non Metric Cranial Variation and Relationships. Unpublished Batchelor of Science (Honours) thesis, Northern Territory University, Darwin, Australia.

Patte, E. 1928. Fouille d'un Kjokkenmodding néolithique dans la province de Thanh Hoa (Indochine). Comptes rendus du Congrès des Sociétés savantes de Paris et des despartement, Lille, Section des Sciences, pp. 186-189.

Patte, E. 1932. Note sur le Préhistoire indochinois. V. Le Kjokken-modding néolithique de Đa Bút (province de Thanh Hoa, Indochine) et ses sépultures. Bulletin du Service Géologique de L'Indochine, 19: 68

Patte, E. 1936 L'Indochine préhistorique. Revue Anthropologique, 46: 277-314.

Pietrusewsky, M. 2006. A multivariate craniometric study of the prehistoric and modern inhabitants of Southeast Asia, East Asia and surrounding regions: a human kaleidoscope? In Oxenham, M.F. and Tayles, N. (eds.) Bioarchaeology of Southeast Asia. Cambridge University Press: Cambridge, pp. 59-90.

Piper, P.J.,, Campos, F.Z., Ngoc Kinh, D., Amano, N., Oxenham, M., Chi Hoang, B., Bellwood, P., and Willis, A. 2014. Early evidence for pig and dog husbandry from the Neolithic site of An Son, Southern Vietnam. International Journal of Osteoarchaeology 24 : 68-78.

Richter, T., Stock, J.T., Maher, L. and Hebron, C. 2010. An Early Epipalaeolithic sitting burial from the Azraq Oasis, Jordan. Antiquity 84: 321-334.

Rispoli, F. 2007. The Incised \& Impressed Pottery Style of Mainland Southeast Asia: Following the Paths of Neolithization. East and West: 235-304.

Sawada, J., Thuy, N.K. and Tuan, N. A. 2011. Faunal remains at Man Bac. In Oxenham, M., Matsumura, H. and Dung, N.K. (eds.) Man Bac: The Excavation of a Neolithic Site in Northern Vietnam. Terra Australis 33. Canberra, Australia: ANU Press, pp. 105-112.

Schlanger, S.H. 1991. On manos, mutates, and the history of site occupations. American Antiquity 56: 460-474.

Sử , N.K.2003. Văn hóa Đa Bút với vấn đề phân vùng kinh tếxã hội đâu tiên trong thời Tiên sử Việt Nam. Khảo $C \hat{o}$ Hoc 3: 88-97.

Sử , N.K. 2012. Khai quật di chỉ mái Đá Vàng. Khảo Cổ Học 5: $80-92$.

Tấn, H.V. 1987. Làng, liên làng và siêu làng - mấy suy nghĩ về phương pháp. Tap Chí Khoa Học, ĐHTH Hà Nội, pp. 1620.

Tấn, H.V. (ed.) 1990. Lich Sủ Thanh Hóa I. Tiên Sủ và Sơ Sủ Nxb KHXH, Hà Nội.

Tấn, H.V. (ed.) 1998. Khảo Cổ Học Việt Nam, I. Thời Dại Dá. Nxb KHXH, Hà Nội.

Thủy, N.K. 1990. Di cốt người cổ Cồn Cổ Ngựa-Thanh Hóa. Khảo Cổ Học 3: 37-48.

Thủy, N.K. 1998. Nhóm máu và kết quả xác định nhóm máu ở Cồn Cổ Ngựa. Khảo Cổ Học 3: 62-71.

Thủy, N.K. 1999. Tư liệu chưa được biết về người cổ Đa BútThanh Hóa. Khảo Cổ Hoc 4: 5-18. 
Thủy, N.K. 2000. Di cốt người cổ Làng Còng. Khai quật lần thư hai Di chỉ đá mói Làng Còng. Tư Liệu Viện $\mathrm{KCH}$, pp. 36-43.

Thủy, N.K. 2004. Cư dân Đa Bút qua tài liệu sinh khảo cổ học. Khảo Cổ Học 1: 15-23.

Trịnh Hoàng Hiệp 2004. Di tích Mán Bạc và mối quan hệ của nó với các di tích Tiên Đông Sơn ở đông bằng sông Hồng, Luận án Thạc sĩ Lịch sử, chuyên ngành Khảo cổ học, Tư liệu Trường Đại học KHXH và NV, Hà Nội.

Trịnh Hoàng Hiệp 2010. Di tích Mán Bạc (Ninh Bình), Luận án Tiến sĩ Lịch sủ̉, chuyên ngành. Tư Liệu Thư Viện Khảo Cổ Học, Hà Nội.

Trịnh Hoàng Hiệp, Masanari, N., Nguyen, C.T. 2003 Kết quả khai quật lần thứ hai di chỉ Mán Bạc (Ninh Bình). Nhũ̃ng Phát Hiện Mới vể Khảo Cổ Học Năm 2002: 156-158.

Trịnh Hoàng Hiệp and Hà Văn Phùng 2003. Di chỉ Đông Vườn - Tư liệu và nhận thức. Khảo Cổ Học: 22-42.

Trịnh Hoàng Hiệp and Hà Văn Phùng 2004. Di chỉ Mán Bạc và mối quan hệ của nó qua tài liệu gốm. Khảo Cổ Học 6:1348.

Turner, C.G. II. 1990. Major features of Sundadonty and Sinodonty, including suggestions about East Asian microevolution, population history, and late Pleistocene relationships with Australian Aboriginals. American Journal of Physical Anthropology 82: 295-317.

Vickers, C. 1947. Burial traits of the Headwaters Lakes aspect in Manitoba. American Antiquity 13: 109-114.

Việt, N. 2003. Văn hóa Đa Bút ứng xử Hoabinhian trước biển tiến Holocen trung. Khảo Cổ Hoc, 3: 18-30.

Vinh, B. 1982a. Cồn Cổ Ngựa (Thanh Hóa)-Một bước ngoặt trong nhận thức về văn hóa Đa Bút. Khảo Cổ Học 1: 1830 .

Vinh, B. 1987. Đa Bút-Văn hóa và văn minh. Khảo Cổ Học 3: 15-31.

Vinh, B. 1991. The Đa Bút culture in the stone age of Vietnam. Bulletin of the Indo-Pacific Prehistory Association 10: 127-131.

Vinh, B. 2002. Lịch sử phát hiện và nghiên cứu văn hóa Đa Bút và quá trình chiếm lĩnh đồng bằng ven biển Thanh Hóa. Khảo Cổ Họ: 12 - 22.

Vinh, B. 2003. Đồ đá văn hóa Đa Bút. Khảo Cổ Học 3: 45-55.

Vượng, T.Q. and Vinh, B. 2003. Đa Bút dưới cái nhìn tông quan về văn hóa Tiên-Sơ sử Việt Nam. Khảo Cổ Học 3: 3-7.

Weber, S., Lehman, H., Barela, T., Hawks, S., Harriman, and D. 2010. Rice or millets: early farming strategies in prehistoric central Thailand. Archaeological and Anthropological Sciences 2: 79-88.

Willis, A. and Tayles, N. 2009. Field anthropology: application to burial contexts in prehistoric Southeast Asia. Journal of Archaeological Science 36: 547-554.

Zhang, M.-L., Zhu, X.Y., Qin, J.G., Wu, X., and Cao, J.H., 2011. Primary Research on the Formation and Development of Zengpiyan Cave and the Ancient Cultural Layer at the Zengpiyan Archaeological Site, Guilin, China. Earth and Environment 3: 5-15. 